\title{
Anchoring the Rock: the Latin Liturgical Cult of Peter in Late Antiquity and the Early Middle Ages
}

\author{
Els Rose
}

The Rock - the Tears: Monothematic Preferences in the Earliest Liturgical Prayers of the Apostle Peter

Now when Jesus came into the district of Caesarea Philippi, he asked his disciples, 'Who do people say that the Son of Man is?' And they said, 'Some say John the Baptist, but others Elijah, and still others Jeremiah or one of the prophets.' He said to them, 'But who do you say that I am?' Simon Peter answered, 'You are the Messiah, the Son of the living God.' And Jesus answered him, 'Blessed are you, Simon son of Jonah! For flesh and blood has not revealed this to you, but my Father in heaven. And I tell you, you are Peter, and on this rock I will build my church, and the gates of Hades will not prevail against it. I will give you the keys of the kingdom of heaven, and whatever you bind on earth will be bound in heaven, and whatever you loose on earth will be loosed in heaven'. ${ }^{1}$

The Gospel according to Matthew is the first written account that framed Peter as the foundation of the Church. The central role Peter played both in the circle of the disciples that accompanied Jesus as described in the Gospels, and in the mission of the apostles that started with Pentecost as depicted in the canonical Acts of the Apostles, is reflected by the representation and veneration of this figure, which crystallised already in the earliest centuries of Christianity and kept developing in later centuries. ${ }^{2}$

An overview of the development of the liturgical cult of the apostle, in the more confined sense of the feasts celebrated through the liturgical year with their prayers and chants, is less easily found. More than fifty years ago now, Joseph Szövérffy expressed his amazement about the lack of a comprehensive study of the liturgical cult of this core apostle and one of the most prominent

1 Matth. 16.13-20 (NRSV).

2 For early Christianity: Apollonj Ghetti (1969); Sotomayor (1962); partim Dijkstra (2016); Burnet (2014). For the medieval period: Lazzari \& Valente Bacci (2001). 
saints of the Latin Church. ${ }^{3}$ In the preceding decades, some studies appeared that eliminated this deficiency albeit only in part. Of these, Szövérffy himself provides a remarkably rich insight into the way the liturgy celebrated Peter, due to his selection of hymn material from a broad geographical and chronological scope. Moreover, even if Szövérffy's study is limited to the single liturgical "genre" of hymns, it has the benefit of dealing with all feasts that developed over the centuries, most importantly the natale of Peter's martyrdom on 29 June, originally shared with Paul, ${ }^{4}$ Peter's Chair on 22 February, ${ }^{5}$ and Peter's Chains on 1 August. ${ }^{6}$

A second liturgical study was published by Victor Saxer a few years after Szövérffy's monograph. ${ }^{7}$ In contrast to the latter, Saxer's study was limited not only to one feast day: 29 June, but also to one liturgical region, namely Rome and the liturgical evidence traditionally linked to that city. The natale of Peter (and Paul) on 29 June is the oldest liturgical feast and has its origin in Rome. It occurs on the Depositio martyrum, incorporated in the Roman Calendar of 354 and known as the oldest liturgical source of urban Rome. ${ }^{8}$

Saxer's study concerns the prayers for Mass used on 29 June and found in the so-called Sacramentarium Veronense, a collection of separate libelli containing one or more Masses for singular feast days, following the calendar from January to December. The single manuscript in which it is transmitted (Verona, Biblioteca capitulare LXXXV [8o]) is dated to the sixth century while the material is generally seen as composed by Roman bishops from the fifth and sixth centuries. ${ }^{9}$ The book contains 28 entries for the natale Petri et Pauli. ${ }^{10}$ Saxer examined the prayers of all these masses and concluded that they concentrate mainly on the apostles' martyrdom and their role as leaders (rectores) and teachers (doctores) of the Church. Although the apostles' martyrdom is at the centre of attention, in line with the theme of the feast day, there is little room for narrative details on this motif, as we will see further below. The prayers are mainly based on scriptural sources. With regard to Peter specifically, the prayers draw from a selection of biblical accounts, mainly Matth. 16.16-9 (Peter

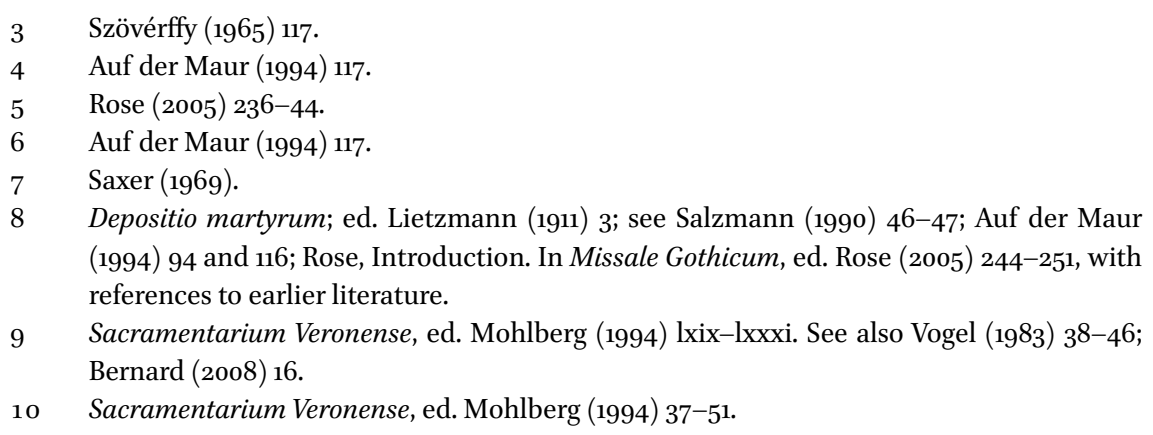


the rock receives the keys of heaven), Lk. 22.31-2 (Christ's promise to ask the Father for a firm faith), and John 21.15-7 (Christ commands his flocks to Peter).

Despite the problematic character of this collection when it comes to pinpointing its specific use, ${ }^{11}$ we must observe the relevance of the Veronense for the study of the earliest liturgical celebration of Peter in the West, given the spread of the material in the book over all regions of Latin Christianity in the early Middle Ages. A close reading of the prayers for 29 June demonstrates that Saxer's conclusions are right. The prayer material for the summer feast of the apostles in this collection is based on canonical Scripture. Moreover, the choice of relevant biblical passages is such that Peter occurs in these prayers as powerful and heroic. Moments of triumph, like Matth. 16 (Tu es Petrus) and John 21 (Pasce oves meas) prevail over moments of crisis, like doubt on the waters (Matth. 14.30-1) and denial and tears (Matth. 26.75) - themes that do not occur at all in this collection. Peter is presented here as a hero of perseverance, granted the privilege to express his faith in Christ through a gloriosa confessio and entrusted with the keys of heaven and, thus, with the authority to forgive and reckon sins. Only two exceptions are found where the apostles, in particular Peter, are not presented as heroes only. In the fifth Mass, the praefatio (294) the first part of the Eucharistic prayer, changing each Sunday and feast day and culminating in the chant Sanctus - comments on Peter's simple background as a fisher: "... and this Peter, once a humble fisherman, unexpectedly became an apostle". ${ }^{12}$ The piscator exiguus needed to go through a transformation in order to become the founder of the Church. The other exception is found in the 24th Mass, where the praefatio (366) describes the process from martyrdom to heavenly bliss the apostles went through with reference to Ps. 125.5:

It is truly worthy [and just that we praise you], for the blessed Peter and Paul your apostles now show to gather with gladness what they sowed under tears. And while they went out weeping, they were not frightened by death, but to receive the fullness of their blessed passion and through sowing the precious seed of their glorious blood, they arrived and behold, they have now come in exultation of the entire church, carrying the fruit of their eternal victory through present and future rewards. ${ }^{13}$

\footnotetext{
11 Bernard (2008) 16.

12 Sacramentarium Veronense 294: ... et ille quondam Petrus piscator exiguus, repente factus apostolus. Ed. Mohlberg (1994) 39.

13 Sacramentarium Veronense 366: Vere dignum: quoniam beatus Petrus et Paulus apostoli tui, quod in lacrimis seminarunt, in gaudio metere nunc probantur. Et qui euntes ibant et flebant, non morte perterriti, sed ut beatae perciperent plenitudinem passionis, gloriosi sanguinis semina praetiosa mittendo, uenientes ecce nunc ueniunt in exultatione totius aeclesiae
} 
The tears mentioned here in quotation of Ps. 125.5 (126.6): qui seminant in lacrimis in exultatione metent clearly do not refer to the tears of repentance found in Matth. 26.75, but to the sorrows of martyrdom foretelling triumph - in later, medieval sources Ps. 125.5 occurs as a tract for martyrs' feasts. ${ }^{14}$

Peter's martyrdom is the only theme found in the Veronense Masses that as such cannot be traced back to biblical sources. The account of Peter's crucifixion is found, in its most extensive form, in the distinctive versions of the apocryphal Acts of Peter, ${ }^{15}$ while it is referred to as a matter of fact in the work of various historians. ${ }^{16}$ However, despite the central role of the theme of martyrdom in the 29June celebration (natale), the liturgical material of the Veronense does not reflect long on the narrative traditions around Peter's death. The only aspect highlighted in this collection is the connection of the event with Rome, stripped from its narrative (apocryphal Acts) or historical (Eusebius) details. The prayers connect Peter's martyrdom directly with the apostle as patron saint - together with Paul - of the city of Rome, a notion that occurs explicitly in a number of prayers in the Veronense. The theme works out in two ways. In the praefatio of the 22nd Mass, the focus is on Rome itself (nostra ciuitas) ${ }^{17}$ and the benefit of the apostles' protection granted to this city as long as its inhabitants faithfully observe the celebration of its patrons and follow their doctrine. In the second example, the Roman patrocinium of Peter (and Paul) is interpreted more extensively as the beginning of the Christianisation of the whole world (per tota mundi regna). This prayer is also found in the fifth Mass (292) and, in a more extended version, as the praefatio (306) of the tenth Mass:

It is worthy [and just that we praise you], who through an ineffable mystery has placed the power of apostolic authority in the city named Rome, so that from there the truth of the Gospel would spread throughout all kingdoms of the world and the universal body of Christian devotion would follow what emanated from their preaching to the entire orb of the earth. And so that through their wholesome help those who deviate

fructum uictoriae sempiternae et praesentibus referentes praemiis et futuris. Ed. Mohlberg (1994) 49-50.

14 Cantus Manuscript Database: http://cantus.uwaterloo.ca/, last consulted 20 November 2017.

15 The earliest explicit evidence is the first letter of Clement, Peter's successor as bishop of Rome: 1 Clement 5; ed. Bihlmeyer (1970) 38; see Burnet (2014) 191-99. For the Acta Petri see also Thacker's contribution to this volume.

16 E.g. Eusebius, Historia ecclesiastica II.25.1, see Burnet (2014) 196.

17 Sacramentarium Veronense 361: Vere dignum: qui praeuidens, quantis nostra ciuitas laboratura esset incommodis, apostolici roboris in eadem praecipua membra posuisti. Ed. Mohlberg (1994) 49 . 
from their track are considered outsiders and only those who do not in any way depart from the principle tradition appear as sons of truth. ${ }^{18}$

The transition from fisherman to apostle entails more than a change of profession or calling. The long way Peter went from the Judean province, central in the Biblical accounts of Peter, to Rome as the heart of the Empire, as depicted by his martyrdom accounts, is presented in this prayer as an essential trajectory in the universal spread of the Christian religion throughout the orbem terrarum. To become a universal religion, Christianity's principle founder needed to be "urbanised"; the successful spread of the novel religion depended on its anchoring in the city that counted as the heart of the realm: Rome itself. ${ }^{19}$ Sources in Transalpine Traditions

If we now turn to the early medieval Latin liturgy outside Rome, in particular North of Alps and Pyrenees, we can see that for sure, not the spread of Christianity as a whole, but the spread of Peter's liturgical cult did emanate from Rome - in that sense the Veronense prayer was answered. The feast of the natale on 29 June as well as the second major Petrine celebration in the liturgical calendar, entitled Cathedra Petri and commemorating Peter's episcopate, travelled from Rome to the regions of Gaul and Spain. ${ }^{20}$ However, these Western provinces of the Roman Empire developed their own liturgical traditions and did not slavishly imitate the model set in Rome. Local traditions played a crucial role in the conservation and development of the feasts, in particular of Peter's Chair, of which no traces are found in the liturgy of Rome between the first attestation in the fourth-century Depositio martyrum on the one hand, and, on the other, the ninth century, when Frankish liturgical material

18 Sacramentarium Veronense 307: Vere dignum: qui ineffabili sacramento ius apostolici principatus in Romani nominis arce posuisti, unde se euangelica ueritas per tota mundi regna diffunderet, et quod in orbem terrarum eorum praedicatione manasset, christianae deuotionis sequeretur uniuersitas; salubrique conpendio et hi, qui ab illorum tramite deuiassent, haberentur externi, et tantummodo filii ueritatis exsisterent, qui a principali nullatenus traditione discederent. Ed. Mohlberg (1994) 41. The first half (until uniuersitas) is also found in Sacramentarium Veronense 294; ed. Mohlberg (1994) 292.

19 A socio-historical explanation of the central role of the city in the Christian mission is given by Meeks (2003) 14-6.

$20 \quad$ Rose (2005) 236-51. 
was adopted by Rome. ${ }^{21}$ Moreover, in terms of content, the liturgical traditions of Gaul and Spain are conspicuous for the innovation they brought to the figure of the apostle Peter by extending, in comparison with the Veronense, the choice of sources and themes when composing the liturgical prayers with which they commemorated him. As we will see below, the composers of liturgical texts in these regions made ample use of apocryphal traditions, which played a much more central role in the liturgical veneration of saints than in the city of Rome. ${ }^{22}$

\section{$2.1 \quad$ Choice of Themes}

To illustrate the innovative character of Peter's liturgical celebration in Spain and Gaul I will concentrate again on the prayers for Mass used on 29 June in both regions. The liturgy of late antique and early medieval Gaul is represented here by the Missale Gothicum, a year-round collection of prayers for Mass transmitted in a single manuscript now in the Vatican Library (Vat. reg. lat. 317), dated around 700, which was probably composed for and used in the urban cathedral of Autun (Burgundy). For Visigothic Spain the transmission of liturgical material is a bit more complicated. The main collection of prayers for Mass more or less contemporary with the Gothic Missal is transmitted in a manuscript of much later date, the so-called Liber mozarabicus sacramentorum, dated to the eleventh century and representing the liturgy of early medieval Toledo. ${ }^{23}$

The Mass for Peter and Paul on 29 June in the Gothic Missal contains prayer material in which, in comparison with the Veronense Masses, a more complete picture of Peter is sketched. The themes present in the Veronense prayers are also central in the Gothic Missal, but the Mass for 29 June in this book also gives room to the fear and doubt that the biblical accounts attribute to Peter. The first and most extensive prayer is the immolatio $(378),{ }^{24}$ a term indicating, in the liturgical tradition of early medieval Gaul, the same first part of the Eucharistic prayer that is called praefatio in the Roman tradition as we have seen above:

21 The lacuna of three quires at the beginning of MS Verona, BC LXXXV [80] (months January to mid-April) makes it impossible to say whether early Masses for Cathedra Petri were originally part of the Veronense collection: Rose, Introduction, in Rose (2005) 236-37.

$22 \quad$ See Rose (2005) 327.

23 Liber mozarabicus sacramentorum, ed. Janini (1982). On the Old Spanish liturgical tradition and the relevant terminology, see the introduction by Ward \& Johnson in their 1995 reprint of Férotin's edition 10-11, and Boynton (2015).

24 Rose (2017) 58-9. 
378 PRAYER OF SACRIFICE. It is truly worthy and just that we always and everywhere bring thanks to you, O Lord, holy Father, almighty and everlasting God, especially today in honour of your most blessed apostles and martyrs Peter and Paul, whom your election has deigned to consecrate to you, such that blessed Peter's worldly art of fishing was converted into a divine doctrine, in order that you would free the human race from the depths of this world with the nets of your teaching. For you changed the heart and the name of his fellow apostle Paul (Acts 13.9), and the Church rejoices that he who first was feared as a persecutor (I Tim. 1.13) is now for her a teacher of heavenly commands. Paul was made blind that he might see (Acts 9.17-18), Peter denied that he might believe (Matth. 26.69-75; John 21.15-19), you handed over to the one the keys of the heavenly kingdom (Matth. 16.18) and you gave to the other the knowledge of divine law in order to call the gentiles. For the latter [Paul] teaches, the former [Peter] opens, both have therefore received the reward of eternal strength. Your right hand raised up the one when he walked on the water, lest he would drown (Matth. 14.28-33), while you helped the other, who was shipwrecked three times (II Cor. 11.25), to withstand the dangers of the deep sea. The one vanquished the gates of hell (Matth. 16.18), the other the sting of death (I Cor. 15.56). Paul was beheaded because he was established by the gentiles as head of the faith, and Peter followed Christ as head of us all while the steps to the cross were laid out beforehand. To whom all [angels] rightly [sing: Holy, holy, holy]. ${ }^{25}$

Missale Gothicum 378: Immolatio missae. Vere dignum et iustum est nos tibi semper et ubique gratias agere, domine, sancte pater, omnipotens aeterne deus, praecipue hodie in honorem beatissimorum apostolorum et martyrum tuorum Petri et Pauli, quos ita electio tua sibi consecrare dignata est, ut beati Petri saecularem piscandi artem in diuinum dogma conuerteret, quatinus humanum genus hac de profundo istius mundi praeceptorum tuorum retibus liberares. Nam cum apostolum eius Paulum mentem cum nomine commutasti et quem prius persecutorem metuebat eclesia nunc caelestium mandatorum laetatur se habere doctorem. Paulus caecatus est ut uideret, Petrus negauit ut crederet; huic claues caelestis imperii tradedisti, illum ad euocandas gentes diuinae legis scientiam contulisti. Nam ille introducit, hic aperit, ambo igitur uirtutes aeternae praemia sunt adepti. Hunc dextera tua gradientem in elemento liquido, ne mergetur, erexit, illum autem tertio naufragantem profunda pelagi fecit uitare discrimina. Hic portas inferni, ille mortis uicit aculeum. Paulus capite plectitur, quia gentibus caput fidei conprobatur, Petrus autem praemissis in cruce uestigiis caput omnium nostrum secutus est Christum. Cui merito omnes. Ed. Rose (2005) 495; transl. Rose (2017) 262-63. 
As said, the immolatio does refer to Peter's transition from a simple fisherman to a preacher of the Gospel and to the biblical account in which Peter is told to receive the keys of the heavenly kingdom. Yet the biblical passages that represent Peter's doubt and fear are, different from the Veronense Masses, not left out in this prayer in the Gothic Missal. Peter is presented in this prayer also as the doubting disciple who had to deny first before he was able to believe, who had to catch the hand of his Master lest he drowned because of little faith.

The second relevant prayer in the Gothic Missal is the prayer of benediction, expressing the words that accompanied the solemn blessing of the people before Communion: ${ }^{26}$

379 Blessing of the people on the feast of the apostles Peter and Paul. God, who made the tears of Peter and the letters of Paul shine as a twinborn light for the members of the Church, by which they are protected against darkness. AMEN.

Look mercifully on this people, you who made that Peter with his key and Paul with his doctrine open the heavens. AMEN.

So that while the leaders show the way, the flock can approach where both equally, the shepherd through the crucifixion and the teacher through the sword, have reached the gathering [of the saints]. Through our Lord. ${ }^{27}$

The prayer highlights, after the reference to Peter's denial in the immolatio, now with more detail Peter's tears shed bitterly when the cock wakened him to his denial (Matth. 26.75). In medieval spirituality, tears - shed by Peter, Mary Magdalene (Lk 7.38), and other saintly figures - symbolise the salutary repentance of the sinner leading to life, ${ }^{28}$ as opposed to Judas' obduracy leading to death. Gregory the Great has already worked out the tears of Peter (and others, like David, Mary Magdalene, and the Thief crucified with Christ) as a wholesome bath that washes away his denial. ${ }^{29}$ Beverly Kienzle has made clear how

26 Rose (2017) 62-3.

27 Missale Gothicum 379: Benedictio populi in natale apostulorum Petri et Pauli. Deus, qui membris eclesiae uelut gemellum lumen, quo caueantur tenebrae, fecisti Petri lacrimas, Pauli litteras coruscare. Amen. Hanc plebem placitus inspice, qui caelos facis aperire Petro in claue, Paulo in dogmate. Amen. Vt praeuiantur ducibus illic grex possit accedere, quo peruenerunt pariter tam ille pastor suspendio, quam iste doctor per gladium in congresso. Per dominum nostrum. Ed. Rose (2005) 496; transl. Rose (2017) 263.

28 Kienzle (2001). On the identification of the anonymous woman washing Christ's feet with tears in Luke 7 with Mary Magdalene, see ibid. 250.

29 Gregory the Great, Homiliae in Ezechielem II.8, lines 579-99; consulted through Brepolis Cross Database Searchtool at www.brepolis.net, last accessed 23 November 2017. See Kienzle (2001) 258-59. 
in the later, medieval sermon tradition tears of repentance are considered as a second baptism after repentance. Thus Peter, in this context often referred to together with Mary Magdalene, functions as a role model and as an example of the repentant sinner. ${ }^{30}$

Let us now turn to the liturgical cult of Peter in early medieval Spain. The Old Spanish Mass ordo ${ }^{31}$ has much in common with the structure of Mass in early medieval Gaul. ${ }^{32}$ Again, two prayers in the Mass for Peter and Paul in the Liber mozarabicus sacramentorum (henceforth LMS) ${ }^{33}$ in particular catch our attention for Peter's tears of repentance, while underlining their salutary effect on the faithful who celebrate his feast. The first is the prayer ad pacem (815), accompanying the exchange of the kiss of peace: ${ }^{34}$

Prayer at the kiss of peace. Almighty Creator and almighty Redeemer, you have placed the letters of Paul and the tears of Peter as two great lights to establish the conversion of the gentiles and the reconciliation of the penitents, so that through your grace neither Paul's persecution, which the love for your Law had imposed on him, nor Peter's denial, which fear of death had required from him, alienated them. Grant us, so we beseech you, to repent after ignorance, to cry after guilt, to recover grace after tears. May Paul, who was not hindered by the fact that he did not know, and Peter, to whom his denial was no lasting obstacle, stand by to further forgiveness in the cases of those who err. ${ }^{35}$

The second relevant prayer is, as in the Gothic Missal, the prayer accompanying the blessing of the people before Communion:

Blessing. Almighty God, who has granted all redemption of faith to the miserable, may grant you to be cleansed by Peter's tears from all contagion of sin. Amen.

$30 \quad$ Kienzle (2001) 258-62.

31 Liber mozarabicus sacramentorum, repr. Ward \& Johnson (1995) 12-5.

32 Rose (2017) 44-65.

33 Liber mozarabicus sacramentorum, ed. Janini (1982) 282-87.

34 Rose (2017) $5^{6-7}$.

35 Liber mozarabicus sacramentorum 815. Ad pacem. Omnipotens conditor, omnipotens et redemptor, qui ad conuersionem gentium et penitentium reconciliationem duo magna luminaria Pauli litteras et Petri lacrymas posuisti, ut a gratia tua nec illum persecutio, quam amor legis intulerat, nec istum negatio, quam timor mortis exegerat, faceret alienos. Da, quesumus, resipiscere post ignorantiam, flere post culpas, gratiam recuperare post lacrimas; adserant apud indulgentiam tuam errantium causas, et Paulus cui non obfuit quod nesciuit, et Petrus cui non inpediit quod negauit. Ed. Janini (1982) 284. 
May he grant that through Paul's teaching you may receive the wisdom of his Word. Amen.

So that the one through penitence, the other through teaching may make you obtain eternal life. Amen. ${ }^{36}$

In these two prayers Peter's remorseful tears are accentuated more than the biblical passages in which he is presented as the solid rock, the fundament and leader of the church. What is more, Peter is clearly positioned here as a model for the faithful. His penitence and contrition are held up as a mirror to the face of the Toledan community celebrating the natale of the saint with these prayers. Their imitation of the repentant model Peter is crucial in their way to eternal salvation. In the Old Spanish Mass for Peter and Paul, the scenes of denial and repentance are presented as more central to the spiritual life of the faithful than the passage on the apostle holding the keys of heaven and able to bind and loose sins.

\section{$2.2 \quad$ Choice of Sources}

Just as the range of thematic variance in the liturgical compositions of Gaul and Spain for 29 June is much larger than in the traditions linked to urban Rome, the same is valid with regard to the sources that inspired the composers of the prayer texts. As we have seen above, the martyrdom of Peter is presented in the Veronense Masses without much historical or narrative detail. This is different in the Gothic Missal and the LMS, where the details of Peter's acts and martyrdom as found in the apocryphal Acts of Peter are highlighted by the prayers.

One of the central episodes in the apocryphal Acts of Peter is his fight with Simon Magus, ${ }^{37}$ a scene that forms the greater part of the prayer after the chant Sanctus in the Spanish LMS, sung after the first part of the Eucharistic prayer (Post Sanctus). ${ }^{38}$ This prayer presents in all detail the struggle of Peter and Paul together against Simon Magus. The story line in itself has its roots in

36 Liber mozarabicus sacramentorum 815: Benedictio. Omnipotens deus, qui omne remedium pietatis tribuit miseris, det uobis Petri lacrimis emundari ab omnibus culpe contagiis. Amen. Concedat doctrina Pauli, percipere uos sapientiam uerbi. Amen. Vt ille per penitentiam, iste per doctrinam, faciant uos peruenire ad uitam aeternam. Amen. Ed. Janini (1982) 287.

Schneemelcher (1997) 253: “... die Auseinandersetzung mit dem Zauberer Simon ist gewissermaßen das Leitmotiv, an das sich die anderen Erzählungen und auch das Martyrium anschließen und das sie ergänzen". See for Simon also Thacker's contribution to this volume. On the complex history of the apocryphal Acts of Peter, see Baldwin (2005).

$38 \quad$ Rose (2017) 60. 
the canonical Acts (Acts 8.9-24), and is elaborated in the apocryphal Acts of Peter where the scene of their controversy is first Samaria, but is then moved to Rome where the culmination of their contest takes place on the Campus Martius. It is to this final stage that the prayer in LMS refers:

After the Sanctus. Osanna in the highest! You, at the same time most high in the highest and humble on earth, Christ son of God. Who has destroyed the dark tricks of the magical art [produced] by Simon's presumptuousness, by revealing the truth in the contest with the apostles. And his boasting (iactantia), deceived by an illusion of demons, elevated him on high, while he vainly tried hard to ascend towards heaven by the motions of the air, only to be severely dashed to pieces, so that, to the extent that his audacity permitted him to fly a little longer, all the more strongly his dismissed insanity while flying broke him. For he did not know that, unless he held the praised confession of Peter or the confidence with which Paul believed, he could not enter the door of heaven of which Peter had the keys, and through whose most secret part Paul had gone in. And he did not remember the sternness and strict judgement of him who had condemned to the punishment of death Ananias and Saffira, who had lied to the Holy Spirit, guilty of delusion and treachery. ${ }^{39}$

The fight with Simon is told in various versions of the Latin Acts of Peter as they circulated in the West. ${ }^{40}$

The second central element of the Acts of Peter is Peter's martyrdom, located in Rome. The final passage of the immolatio (378) in the Gothic Missal, quoted in the previous section, hints at Peter's crucifixion head-down:

39 Liber mozarabicus sacramentorum 817: Post sanctus. Osanna in excelsis! Idem excelse in excelsis, idem humilis in terrenis, Christe filius dei. Qui nebulosa magice artis in Simonis presumptione prestigia, apostolice concertationis ueritate prodita destruxisti. Quem frustra caelorum ascensum aeris mollitionibus adpetentem, decepta demonum inlusione iactantia altius extulit, grauius elidendum, ut quo eum paulo longius sursum uolandi audacia permissa sustolleret, multo ualidius in deorsum uolantis insania dimissa disrumperet: nescientem utique quod, nisi laudatam Petri confessionem, nisi creditam Pauli fidem teneret, caeli cuius claues Petrus habebat, et cuius Paulus intima penetrauerat, ianuam non intraret. Inmemor etiam illius seueritatis atque censure, qui Ananiam et Saffiram sancto spiritui mentientes, preuaricationis et perfidie reos, presentis mortis animaduersione damnauit. Ed. Janini (1982) 286.

40 Baldwin (2005) 26-62 gives an overview of Latin sources and (early) modern editions and studies. The most elaborate account of the fight with Simon Magus is in the Actus Vercellenses, ed. Lipsius (1898). See, for a collection of articles on the figure of Simon Magus, Ferreiro (2005). 
Peter followed Christ as head of us all while the steps to the cross were laid out beforehand.

The passage leaves room for diverse interpretations, as I explained elsewhere. ${ }^{41}$ The words praemissis [...] uestigiis [...] secutus est Christum can be understood as a response to the Gospel passage John 21.18-22, where Peter's martyrdom is considered to be predicted by Christ, followed by the call tu me sequere (John 21.22). However, it is also possible that the phrase is taken from the famous Quo vadis legend included in the Acts of Peter. This passage narrates how Peter met Christ when he was urged by the Christian community of Rome to run away from the city where martyrdom threatened him, and how Christ called him back to undertake this martyrdom. ${ }^{42}$ The emphasis on the uestigia (footsteps) with which Christ preceded Peter gives cause to consider the apocryphal narrative a more plausible background to this quotation than the biblical passage. Peter uses the same word in his speech to the Roman prefect Agrippa (whose aim to kill the apostle drove Peter away from Rome in the first place), claiming that his martyrdom is necessitated by his wish to imitate Christ: et desidero eius sequi uestigia passionis. ${ }^{43}$

The reference to Peter's speech to Agrippa in the Gothic Missal positions his martyrdom in the concrete setting of Rome where his martyrdom eventually took place. Likewise, the narrative on Simon Magus gives the prayer in the LMS a distinct Roman aura. The city of Rome may have left its mark on the Veronense Masses, particularly the prayers that were clearly written for the local Roman community (nostra ciuitas) ${ }^{44}$ as the symbolic centre of the Christianising Empire. Yet the composers of liturgical prayers in early medieval Gaul and Spain no less emphasised the Roman roots and urban character of Peter's cult when they tried to innovate the liturgical celebration of this saint for their own communities. The local popularity of the Rock in the more northern regions of Latin Christianity, which becomes evident from the numerous churches and monasteries dedicated to Peter ${ }^{45}$ never lost track of the Roman origins of this cult.

\footnotetext{
41 Rose (2017) 263; see also Burnet (2014) 190-91, 193.

42 Martyrium Petri (Ps-Linus) c. 6, ed. Lipsius (1891/1990) 7-8.

43 Martyrium Petri (Ps-Linus) c. 8, ed. Lipsius (1891/1990) 10.

44 See footnote 17.

45 Ewig $(1976-79)$.
} 
The sources from which authors of liturgical texts took their inspiration to create the liturgical cult of Peter the saint are manifold. Likewise, the themes that dominate the liturgical celebration of his feast day are multifaceted and do justice to the multifarious character of this core apostle. The Rock of Matth. 16 is celebrated in many ways, but just as central to the liturgical cult are the images of the repentant sinner and the doubtful believer, providing a more imitable mimetic model for others to follow. The choice of sources that underlie the liturgical portrait of Peter shows that every effort was made to add to the innovative quality of Peter's cult, even more so outside Rome than in Rome itself.

The transition from the simple fisherman to the urban patron saint Peter became in and through Rome could not be established on the ground of biblical sources alone. Although the urban dimension is present in the canonical book of Acts, where Peter operates in Jerusalem, the biblical narrative does not position this apostle in Rome. ${ }^{46}$ Establishing a liturgy that celebrated Peter as Roman martyr and, thereby, celebrating also in a liturgical setting Roma nova, now protected by the Christian patron saint as new "founder", was only possible with the help of other than biblical sources, among which the apocryphal Acts of Peter take central stage. This intervention was particularly successful in regions where the composers of liturgical prayers and chants for saints traditionally made ample use of narrative material taken from hagiography and, in the case of biblical saints, the apocrypha. ${ }^{47}$ The fact that the liturgical traditions in which Rome is presented in most detail as the setting of Peter's mission and martyrdom developed primarily outside Rome and in the former provinces is one of the most striking paradoxes of the history of Latin liturgy. This conclusion is probably biased by the result of the remarkable lack of relevant sources of the liturgy of late antique Rome..$^{48}$ More directly it shows the remarkable richness of the other Latin traditions and the way liturgy was celebrated outside Rome as the presupposed centre of the Latin Church. This richness of non-Roman sources provides us with a dynamic and multi-coloured picture of the liturgical veneration of Peter in the earliest period of his cult.

46 Unless 1 Peter 5.13 is a hidden reference to Rome: see Burnet (2014) 192-93 with further bibliographical references.

47 Such as Gaul and Spain, see above footnote 22.

48 Bernard (2008) 15-19. 


\section{Acknowledgement}

I followed the orthography found in the editions used without additional explanation of (sometimes notable) deviations from the classical norm. This article was published with financial support from NWO VICI 277-30-002 Citizenship Discourses in the Early Middle Ages, 400-1100 (2017-2022).

\section{Bibliography of Primary Sources}

MS Verona, Biblioteca capitulare LXXXV [80].

MS Bibliotheca apostolica Vaticana, reg. lat. 317.

Acta Petri. Transl. Poupon, G. (1997). Actes de Pierre. In Écrits apocryphes chrétiens I, 1039-1114. Paris: Gallimard.

Acta Petri (= Actus Vercellenses). Ed. Lipsius, R. 1891/1990. Acta apostolorum apocrypha I, 45-103. Leipzig/repr. Hildesheim.

Depositio martyrum. Ed. Lietzmann, H. 1911. Die drei ältesten Martyrologien. Bonn.

Eusebius of Caesaria/Rufinus, Historia ecclesiastica. Ed. Mommsen, Th. 1903. Die griechischen christlichen Schriftsteller der ersten dreiJahrhunderte, vol. 2.1-3. Leipzig: Hinrich.

Gregory the Great, Homiliae in Ezechielem. Ed. Adriaen, M. 1971. Corpus Christianorum series Latina 142. Turnhout: Brepols.

Liber mozarabicus sacramentorum. Ed. Janini, J. 1982. Liber missarum de Toledo:y libros misticos. Toledo: Instituto de Estudios Visigótico-Mozáribes.

Martyrium Petri (Ps-Linus). Ed. Lipsius, R. 1891/1990. Acta apostolorum apocrypha I, 1-22. Leipzig/repr. Hildesheim.

Missale Gothicum. Ed. Rose, E. 2005. E codice Vaticano Reginensi Latino editum. Turnhout: Brepols, Corpus Christianorum series Latina 159D.

Sacramentarium Veronense. Ed. Mohlberg, L. 1994. Sacramentarium Veronense, 3rd. edition. Rome: Herder.

\section{Bibliography of Secondary Sources}

Auf der Maur, H.-J. 1994. Feiern im Rhythmus der Zeit vol. 2.1, ed. Harnoncourt, Ph. \& H.-J. Auf der Maur. Gottesdienst der Kirche: Handbuch der Liturgiewissenschaft VI.1. Regensburg: Pustet.

Baldwin, M. C. 2005. Whose Acts of Peter? Text and Historical Context of the Actus Vercellenses. Tübingen: Mohr Siebeck. 
Bartolozzi Casti, G. 2001. La diffusione del culto di S. Pietro in vincoli. In La figura di San Pietro nelle fonti del medioevo, ed. Lazzari, L. \& A. M. Valente Bacci, 70-80. Louvain-la-Neuve: FIDEM.

Bernard, Ph. 2008. Transitions liturgiques en Gaule carolingienne. Une traduction commentée des deux «lettres » faussement attribuées à l'évêque Germain de Paris (fin du $V_{I I I}{ }^{e}$ siècle). Paris: Hora decima.

Boynton, S. 2015. Restoration or Invention? Archbishop Cisneros and the Mozarabic Rite in Toledo. Yale Journal of Music and Religion 1: 5-30.

Burnet, R. 2014. Les douze apôtres. Histoire de la réception des figures apostoliques dans le christianisme ancien. Turnhout: Brepols.

Dijkstra, R. 2016. The Apostles in Early Christian Art and Poetry. Leiden: Brill.

Ewig, E. 1976-1979. Spätantikes und fränkisches Gallien: Gesammelte Schriften (19521973), ed. Hartmut Atsma. Munich: Artemis.

Ferreiro, A. 2005. Simon Magus in Patristic, Medieval and Early Modern Traditions. Leiden: Brill.

Kellner, K. A. H. Heortologie oder die geschichtliche Entwicklung des Kirchenjahres und der Heiligenfeste von den ältesten Zeiten bis zur Gegenwart. Freiburg i.B.: Herder.

Kienzle, B. M. 2001. Penitents and Preachers: The Figure of Saint Peter and His Relationship to Saint Mary Magdalene. In Lazzari \& Valente Bacci, 248-72. Louvain-la-Neuve: FIDEM.

Lazzari, L. \& A. M. Valente Bacci, eds. 2001. La figura di San Pietro nelle fonti del medioevo. Louvain-la-Neuve: FIDEM.

Meeks, W. A. 2003. The First Urban Christians. The Social World of the Apostle Paul, second edition. New Haven/London: Yale University Press.

Rose, E. 2017. The Gothic Missal: Introduction, Translation and Notes. Turnhout: Brepols.

Salzman, M. 1990. On Roman Time: The Codex-Calendar of 354 and the Rhythms of Urban Life in Late Antiquity. Berkeley CA: University of California Press.

Saxer, V. 1969. Le culte des apôtres Pierre et Paul dans les plus vieux formulaires romains de la messe du 29 juin. Recherches sur la thématique des sections XV-XVI du Sacramentaire Léonien. In Saecularia Petri et Pauli. Conferenze per il centenario del martirio degli apostoli Pietro et Paolo tenute nel Pontificio Istituto di Archeologica Cristiana, ed. Apollonj Ghetti B. M., 199-240. Città del Vaticano: Pontifico Istituto di Archeologia Cristiana.

Schneemelcher, W. 1997. Neutestamentliche Apokryphen II: Apostolisches, Apokalypsen und Verwandtes. Tübingen: Mohr.

Sotomayor, M. 1962. S. Pedro en la iconografía paleocristiana: testimonios de la tradición cristiana sobre San Pedro en los monumentos iconográficos anteriores al siglo sexton Granada: Facultad de teologia.

Szövérffy, J. 1965. A Mirror of Medieval Culture. Saint Peter Hymns of the Middle Ages. New Haven, CT: The Academy. 
Ward, A. \& C. Johnson. 1995. Introduction to the reprint of Férotin, M. 1912. Le liber mozarabicus sacramentorum et les manuscrits mozarabes. Roma: CLV Edizioni liturgiche.

Brepolis Cross Database Searchtool: www.brepolis.net/cds/pages/Search.aspx.

Cantus Manuscript Database: http://cantus.uwaterloo.ca/. 